\title{
DYNAMICS AND TRENDS OF THE DEVELOPMENT OF TRANSPORT RELATIONS IN ROAD FREIGHT TRAFFIC
}

\author{
Marijan Rajsman, Grgo Luburić, Matija Muhin
}

Subject review

This paper investigates the structure of transport relations in the Croatian road freight transport system. The paper is based on data from the Croatian Central Bureau of Statistics, according to statistical reports entitled "Transport and communications". The observed period is $2002 \div 2012$. It analyzes the absolute and relative structure of transport relations according to the established categories in the Croatian road freight transport. It includes the graphical analysis of absolute and relative structure of transport relations in the Croatian road freight transport, according to the amount of road freight substrate and realised transport performance through the studied categories of transport relations. It analyzes the structure of transport relations of road freight substrate in the Croatian transport system, with the use of mathematical statistics, above all mathematical forecasting models to evaluate statistical significance regarding the trend of the studied variable. The survey established statistically significant trends of changes in the structure of transport relations and their absolute and relative share in meeting freight transport demand as well as the realised transport performance on these relations.

Keywords: dynamics and trends of tansport relations; road freight substrate; road transportation

Dinamika i trendovi razvitka transportnih relacija u cestovnom teretnom prometu

Pregledni članak

Ovim radom izučava se struktura transportnih relacija u hrvatskom cestovnom teretnom prometnom sustavu. Rad se temelji na podacima Državnog zavoda za statistiku Republike Hrvatske prema statističkim izvješćima pod nazivom „Transport i komunikacije“. Izučavano je vremensko razdoblje od 2002. $\div$ 2012. godine. Analizira se apsolutna i relativna struktura transportnih relacija prema utvrđenim kategorijama u hrvatskom cestovnom teretnom prometu. Vrši se grafička analiza apsolutne i relativne strukture transportnih relacija u hrvatskom cestovnom teretnom prometu prema količini cestovnog teretnog supstrata i ostvarenom transportnom radu prema izučavanim kategorijama transportnih relacija. Analizira se struktura transportnih relacija cestovnog teretnog supstrata u hrvatskom prometnom sustavu, uz korištenje metoda matematičke statistike, prije svega matematičkih prognostičkih modela kojima se ocjenjuje statistička signifikantnost trenda izučavane varijable. Istraživanjem su ustanovljeni statistički signifikantni trendovi promjena u strukturi transportnih relacija i njihovoga apsolutnog i relativnog udjela podmirenju teretne transportne potražnje kao i ostvarenom transportnom radu na tim relacijama.

Ključne riječi: cestovni promet; cestovni teretni supstrat; dinamika i trendovi transportnih relacija

\section{Introduction}

Transport modelling is an important factor in optimizing the transport system $[1 \div 5]$. Data on road freight substrate and realised freight transport performance were obtained in accordance with the methodological rules and principles of the Statistical Office of the European Union (Eurostat), in accordance with the EU Regulation no. 70/12 of 18 January 2012 on statistical reports relating to the carriage of goods by road and the pertinent regulations. The aim of the research of road transport is collecting, processing and publishing data on the volume of road transport, business entities engaged in the transport of goods, whether by public transport or on their own account [6]. Since this is a quantitative research, the dynamic measurements were used regarding the average annual growth rate and determining the trend of the value of the studied sizes. Knowledge about the dynamics of development of the studied size and its possible laws, or trends of development in the transport system represent a scientifically based foundation for dimensioning of the entire organization of work, necessary transport capacities and making strategic decisions for further development of the transport system. Traffic planning in the new millennium is determined by the need to constantly increase the capacity of the transport system to meet the increase in transport demand [1, 3, 4, 7]. The focus of traffic planners and managers is not only anticipating and ensuring the necessary transport infrastructure and superstructure, but also its better utilization with priority consideration given to requirements of transport services user. According to Padjen, transport demand is of vital importance for the establishment and management of transport policy, it determines the development of the transport system, as well as the degree of its exploitation primarily its technical strata, transport infrastructure and means of transport [8].

\section{Transport relations in Croatian road freight transport}

Transport relations in the Croatian road freight transport are divided into four groups or categories, according to the relation in which the transport was conducted. These categories are the following: 1) short distances up to $49 \mathrm{~km}, 2$ ) medium distances of $50 \div 149$ $\mathrm{km}$, 3) long distances of $150 \div 499$ kilometers and 4) distances greater than $500 \mathrm{~km}$.

According to Tab. 1, from the analysis of the absolute structure of road freight transport substrate it can be concluded that in the Croatian road transport system in the period from 2002 to 2012 :

a) the average amount of total road freight transport substrate is 73562 million tons, with an average annual growth rate of road freight transport substrate of $3,6 \%$,

b) at distances up to $49 \mathrm{~km}$ an average of 40920 million tons of road freight substrate has been transported, with an average annual growth rate of 5,2\%,

c) at distances of 50 to $149 \mathrm{~km}$ an average of 16,311 million tons of road freight has been transported, with an average annual growth rate of $2 \%$, 
d) at distances of 150 to $499 \mathrm{~km}$ an average of 12218 million tons of road freight substrate has been transported, with an average annual growth rate of 2,2 $\%$,

e) at distances over $500 \mathrm{~km}$ an average of 4112 million tons has been transported, with an average annual growth rate of $1 \%$.

By the analysis of the data in Tab. 1, it is also possible to determine that the amount of transported cargo on relations up to $49 \mathrm{~km}$ during the period from 2002 to 2012 in Croatian road transport system was gradually increasing, especially from 2002 to 2006, but in that category of transport relations from 2007 to the end of the studied period there was a statistically significant downward trend. (Fig. 1) This trend, which in terms of the benefits of road transport in relation to other transport systems on those relations is most advantageous due to the elasticity in the provision of a transport service called "transport from door to door", is by no means favourable.

Table 1The absolute structure of freight transport substrate according to transport relations in the Croatian transport system for the period from 2002 to 2012

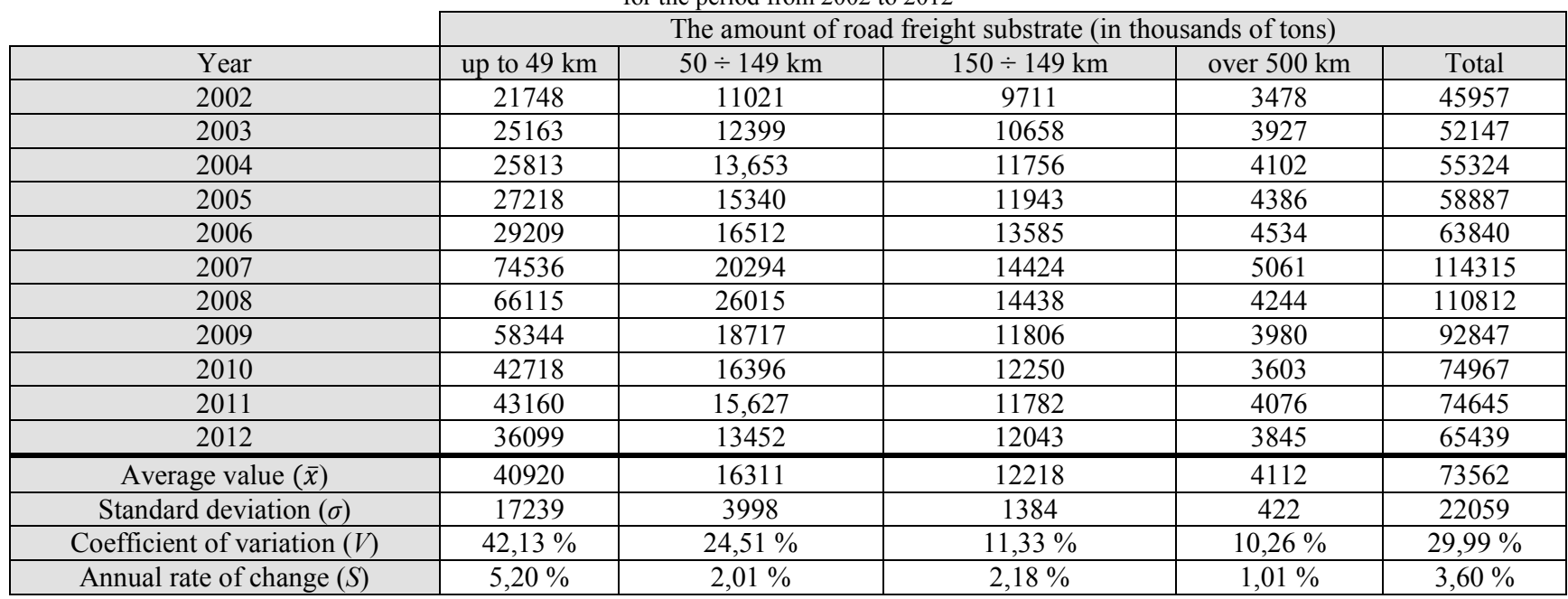

Source: Transport and Communications in 2006, Statistical reports, Zagreb, 2007, p. 64, Transport and Communications in 2011, Statistical reports, Zagreb, 2012, p. 49, Transport and Communications in 2012, Statistical reports, Zagreb, 2013, p. 50.

Table 2 The relative structure of freight transport substrate according to transport relations in the Croatian transport system for the period from 2002 to 2012

\begin{tabular}{|c|c|c|c|c|c|}
\hline \multirow[b]{2}{*}{ Year } & \multicolumn{5}{|c|}{ The relative share of road freight transport substrate on a transport relation $(\%)$} \\
\hline & up to $49 \mathrm{~km}$ & $50 \div 149 \mathrm{~km}$ & $150 \div 499 \mathrm{~km}$ & over $500 \mathrm{~km}$ & Total \\
\hline 2002 & 47,32 & 23,98 & 21,13 & 7,57 & 100,00 \\
\hline 2003 & 48,25 & 23,78 & 20,44 & 7,53 & 100,00 \\
\hline 2004 & 46,66 & 24,68 & 21,25 & 7,41 & 100,00 \\
\hline 2005 & 46,22 & 26,05 & 20,28 & 7,45 & 100,00 \\
\hline 2006 & 45,75 & 25,86 & 21,28 & 7,10 & 100,00 \\
\hline 2007 & 65,20 & 17,75 & 12,62 & 4,43 & 100,00 \\
\hline 2008 & 59,66 & 23,48 & 13,03 & 3,83 & 100,00 \\
\hline 2009 & 62,84 & 20,16 & 12,72 & 4,29 & 100,00 \\
\hline 2010 & 56,98 & 21,87 & 16,34 & 4,81 & 100,00 \\
\hline 2011 & 57,82 & 20,94 & 15,78 & 5,46 & 100,00 \\
\hline 2012 & 55,16 & 20,56 & 18,40 & 5,88 & 100,00 \\
\hline Average value $(\bar{x})$ & 53,81 & 22,65 & 17,57 & 5,98 & - \\
\hline Standard deviation $(\sigma)$ & 6,88 & 2,48 & 3,43 & 1,41 & - \\
\hline Coefficient of variation $(V)$ & 12,78 & 10,97 & 19,54 & 23,64 & - \\
\hline Annual rate of change $(S)$ & 1,55 & $-1,53$ & $-1,37$ & $-2,50$ & - \\
\hline
\end{tabular}

Source: Transport and Communications in 2006, Statistical reports, Zagreb, 2007, p. 64, Transport and Communications in 2011, Statistical reports, Zagreb, 2012, p. 49, Transport and Communications in 2012, Statistical reports, Zagreb, 2013, p. 50.

From Tab. 2, which shows the relative structure of transport relations regarding their share in the structure of total road freight substrate in the Croatian road transport in the period from 2002 to 2012 , we can conclude the following:

a) the average value of the share of road freight transport substrate at distances up to $49 \mathrm{~km}$ is $53,8 \%$, with an average annual growth rate of $1,5 \%$, b) the average value of the share of road freight transport substrate at distances from 50 to $149 \mathrm{~km}$ is $22,6 \%$, with an average annual decline of $-1,5 \%$,

c) the average value of the share of road freight transport substrate at distances from 150 to $499 \mathrm{~km}$ is $17,6 \%$, with an average annual decline of $-1,4 \%$,

d) the smallest share of road freight substrate is at distances greater than $500 \mathrm{~km}$ and has an average value of $6 \%$, with an average annual decline of $-2,5$ $\%$. 
Table 3 The absolute structure of freight transport performance according to transport relations in the Croatian road transport system for the period from 2002 to 2012

\begin{tabular}{|c|c|c|c|c|c|}
\hline \multirow{3}{*}{ Year } & \multicolumn{5}{|c|}{ Transport relations } \\
\hline & $<49 \mathrm{~km}$ & $50 \div 149 \mathrm{~km}$ & $150 \div 499 \mathrm{~km}$ & $>500 \mathrm{~km}$ & $\begin{array}{c}\text { Total } \\
\text { transport } \\
\text { performance } \\
\text { (million tkm) }\end{array}$ \\
\hline & \multicolumn{5}{|c|}{ Transport performance (million tonne-kilometres) } \\
\hline 2002 & 422 & 919 & 2666 & 3406 & 7413 \\
\hline 2003 & 503 & 1064 & 2934 & 3741 & 8242 \\
\hline 2004 & 516 & 1130 & 3261 & 3913 & 8820 \\
\hline 2005 & 531 & 1271 & 3352 & 4175 & 9329 \\
\hline 2006 & 597 & 1432 & 3918 & 4228 & 10175 \\
\hline 2007 & 1189 & 1625 & 3953 & 4662 & 11429 \\
\hline 2008 & 1122 & 2051 & 4016 & 3853 & 11042 \\
\hline 2009 & 1032 & 1513 & 3317 & 3567 & 9429 \\
\hline 2010 & 763 & 1310 & 3346 & 3361 & 8780 \\
\hline 2011 & 758 & 1241 & 3239 & 3688 & 8926 \\
\hline 2012 & 643 & 1083 & 3279 & 3644 & 8649 \\
\hline Average value $(\bar{x})$ & 734 & 1331 & 3389 & 3840 & 9294 \\
\hline Standard deviation $(\sigma)$ & 255 & 302 & 402 & 370 & 1132 \\
\hline Coefficient of variation $(V)$ & $34,71 \%$ & $22,69 \%$ & $11,87 \%$ & $9,64 \%$ & $12,18 \%$ \\
\hline Annual rate of change $(S)$ & $4,30 \%$ & $1,66 \%$ & $2,09 \%$ & $0,68 \%$ & $1,55 \%$ \\
\hline
\end{tabular}

Source: Transport and Communications in 2006, Statistical reports, Zagreb, 2007, p. 64, Transport and Communications in 2011, Statistical reports, Zagreb, 2012, p. 49, Transport and Communications in 2012, Statistical reports, Zagreb, 2013, p. 50.

Table 4 The relative structure of freight transport performance according to transport relations in the Croatian road transport system for the period from 2002 to 2012

\begin{tabular}{|c|c|c|c|c|c|}
\hline & \multicolumn{5}{|c|}{ The share of transport relation according to the realised freight transport performance $(\%)$} \\
\hline Year & up to $49 \mathrm{~km}$ & $50 \div 149 \mathrm{~km}$ & $150 \div 149 \mathrm{~km}$ & over $500 \mathrm{~km}$ & Total \\
\hline 2002 & 5,69 & 12,40 & 35,96 & 45,95 & 100,00 \\
\hline 2003 & 6,10 & 12,91 & 35,60 & 45,39 & 100,00 \\
\hline 2004 & 5,85 & 12,81 & 36,97 & 44,37 & 100,00 \\
\hline 2005 & 5,69 & 13,62 & 35,93 & 44,75 & 100,00 \\
\hline 2006 & 5,87 & 14,07 & 38,51 & 41,55 & 100,00 \\
\hline 2007 & 10,40 & 14,22 & 34,59 & 40,79 & 100,00 \\
\hline 2008 & 10,16 & 18,57 & 36,37 & 34,89 & 100,00 \\
\hline 2009 & 10,94 & 16,05 & 35,18 & 37,83 & 100,00 \\
\hline 2010 & 8,69 & 14,92 & 38,11 & 38,28 & 100,00 \\
\hline 2011 & 8,49 & 13,90 & 36,29 & 41,32 & 100,00 \\
\hline 2012 & 7,43 & 12,52 & 37,91 & 42,13 & 100,00 \\
\hline Average value $(\bar{x})$ & 7,76 & 14,18 & 36,49 & 41,57 & - \\
\hline Standard deviation $(\sigma)$ & 1,98 & 1,74 & 1,20 & 3,33 & - \\
\hline Coefficient of variation $(V)$ & 25,47 & 12,24 & 3,28 & 8,01 & - \\
\hline Annual rate of change $(S)$ & 2,71 & 0,10 & 0,53 & $-0,86$ & - \\
\hline
\end{tabular}

Source: Transport and Communications in 2006, Statistical reports, Zagreb, 2007, p. 64, Transport and Communications in 2011, Statistical reports, Zagreb, 2012, p. 49, Transport and Communications in 2012, Statistical reports, Zagreb, 2013, p. 50.

According to Tab. 3, from the analysis of the absolute structure of road freight transport performance in the Croatian road transport system in the period from 2002 to 2012, it can be concluded that:

a) the realised freight transport performance at distances up to 49 kilometers amounts on average to 734 million tonne-kilometres (hereinafter tonne kilometers $=\mathrm{tkm})$, with an average annual growth rate of $4,3 \%$,

b) the realised freight transport performance at distances from 50 to 149 kilometers amounts on average to 1331 million tkm, with an average annual growth rate of $1,7 \%$,

c) at distances from 150 to $499 \mathrm{~km}$, the average value of the transport performance is 3389 million tkm, with an average annual growth rate of $2,1 \%$,

d) relations which showed the most significant value of realised transport performance are the relations greater than $500 \mathrm{~km}$, with an average value of 3840 million tkm, and an average annual growth rate of 0,7 $\%$,

e) the average value of the total transport performance is 9294 million tkm, while the average annual growth rate is $1,5 \%$.

The relative structure of the realised freight transport performance according to the transport relations in the Croatian road freight transport for the period 2002 to 2012 is shown in Tab. 4 below.

According to Tab. 4 and the analysis of the relative structure of the realised freight transport performance over transport relations in the Croatian road freight transport in the period from 2002 to 2012, it is possible to

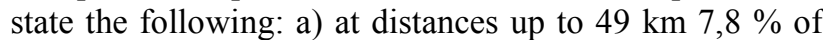
the total transport performance was realised, with an average annual growth rate in the relative share of $2,7 \%$, 
b) at distances from 50 to $149 \mathrm{~km}, 14,2 \%$ of the total transport performance was realised, with an average annual growth rate in the relative share of $0,1 \%, c)$ at distances from 150 to $499 \mathrm{~km}, 39,5 \%$ of the total transport performance was realised, with an average annual growth rate in the relative share of $0,5 \%, \mathrm{~d}$ ) at distances greater than $500 \mathrm{~km}$ an average of $41,6 \%$ of the total transport performance was realised, with an average annual decline in the relative share of $-0,9 \%$.

\section{Dynamics and trends in the structure of freight substrate and transport performance on the transport relations in road transport system}

This chapter shall present the additional analysis of the dynamics and absolute and relative structure of the freight substrate and transport performance by category of transport relations in the Croatian road transport system. Accordingly, appropriate graphical representations are used, as well as methods of mathematical statistics in order to design mathematical prognostic trend models with evaluation of statistical significance regarding the trend of the studied variable. The survey identified time periods within which it was possible to determine statistically significant trends.

Figs. 1 and 2 show the dynamics of changes in the absolute and relative structure of road freight transport substrate according to the studied categories of transport relations. During the observed period, the amount of road freight substrate has a gradual upward trend until 2006, with a maximum road freight substrate at distances up to $49 \mathrm{~km}$. Other transport relations achieved a slight increase until 2008, with the second highest growth rate (immediately after distances up to $49 \mathrm{~km}$ ) achieved at distances from 150 to $499 \mathrm{~km}$. After 2008, in accordance with the onset of the Croatian economic recession, the amount of road freight substrate has the downward trend on all transport relations. This downward trend in value is more significant at short distances than on other transport relations.

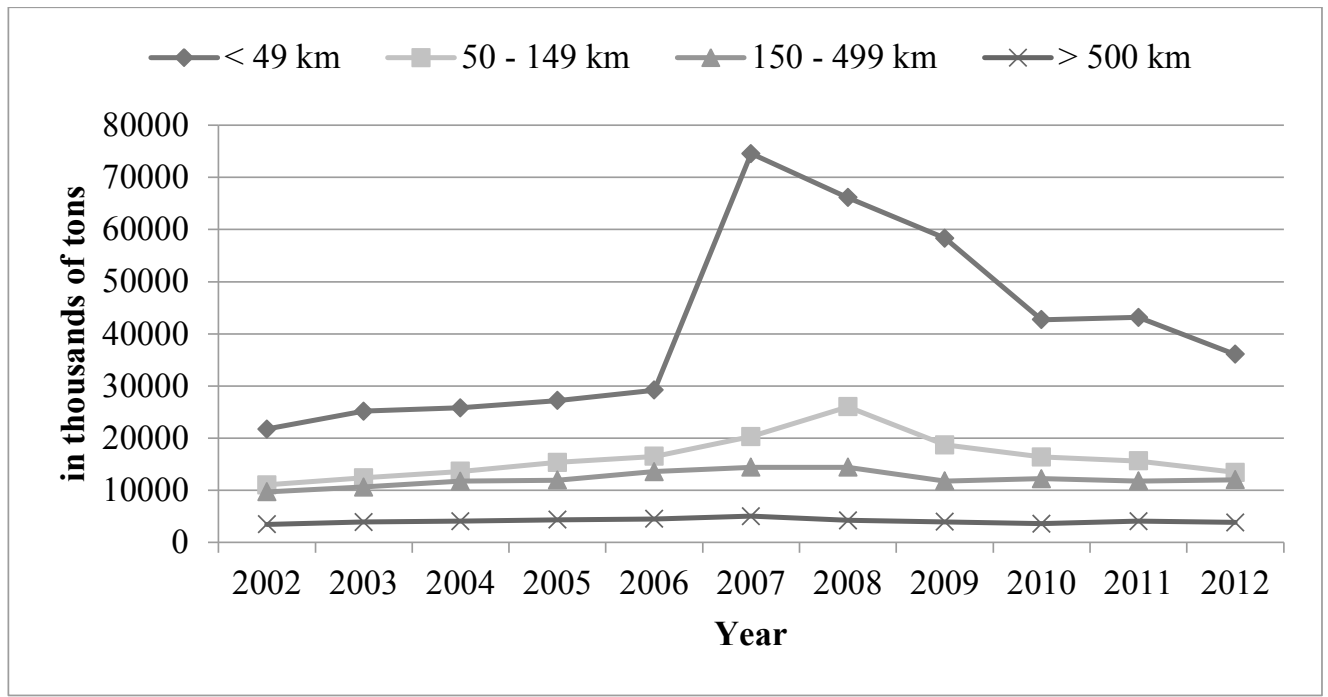

Figure 1 The absolute structure of freight transport substrate dynamics according to transport relations in the Croatian transport system for the period from 2002 to 2012; Source: Tab. 1

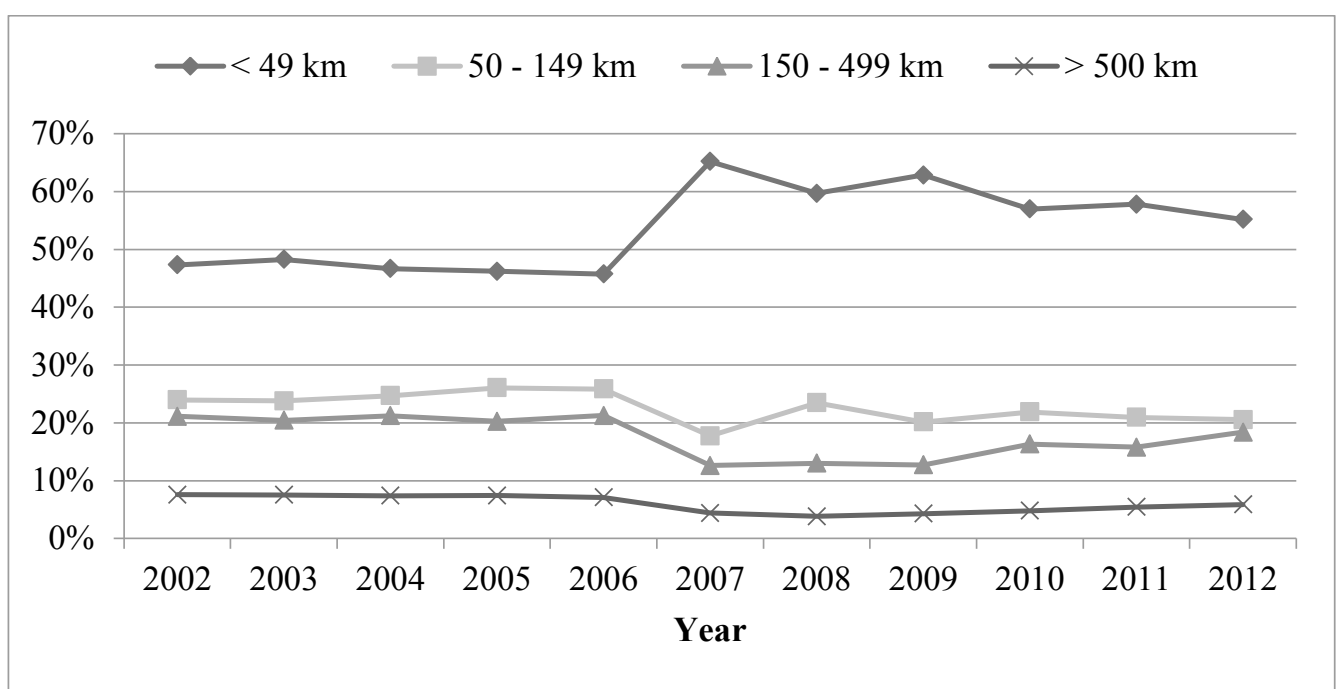

Figure 2 The relative structure of freight transport substrate dynamics according to transport relations in the Croatian transport system for the period from 2002 to 2012; Source: Tab. 2 


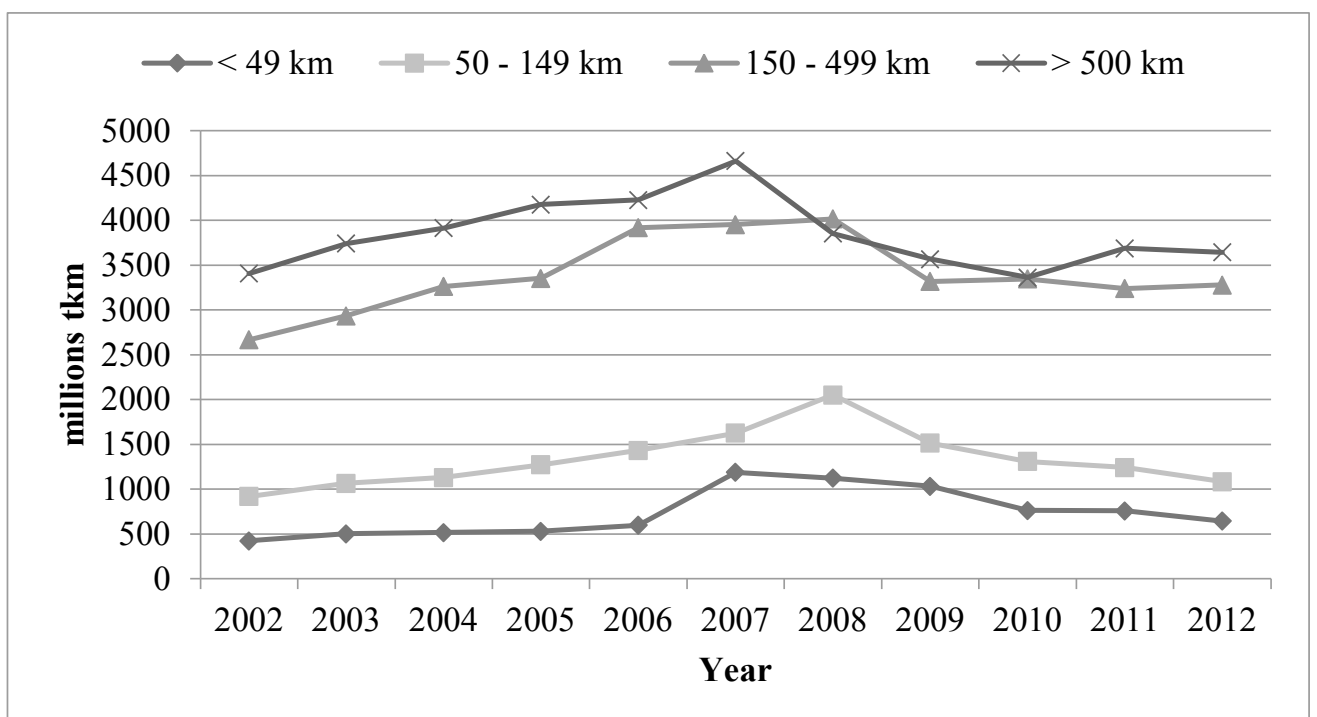

Figure 3 The absolute structure of freight transport performance dynamics according to transport relations in the Croatian road transport system for the period from 2002 to 2012; Source: Tab. 3

Figs. 3 and 4 show the dynamics of changes in the absolute and relative structure of the realised freight transport performance according to transport relations in the Croatian road transport system from 2002 to 2012. Within the period from 2002 to 2006 on all relations there were no significant changes in the structure of the share so that at distances up to $49 \mathrm{~km}$ an average of $46,8 \%$ of the total transport performance was achieved, b) at

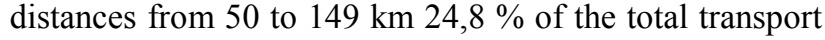
performance was achieved, c) at distances from 150 to $499 \mathrm{~km} \mathrm{20,9 \%}$ of the total transport performance was

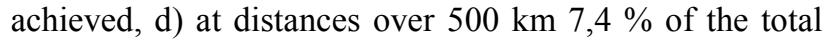
transport performance was achieved. After 2007, the upward trend in freight transport performance is achieved only at distances up to $49 \mathrm{~km}$ and with an increase of 20 $\%$ over a period of one year. On other relations there is a steady downward trend of the realised freight transport performance. Since 2008, this downward trend is the result of growth in the share of transport relations from 150 to $499 \mathrm{~km}$, and at distances greater than $500 \mathrm{~km}$. Declining trend in the share of relations with respect to the realised transport performance at distances up to 49 $\mathrm{km}$ and those from 50 to $149 \mathrm{~km}$ was achieved in the period from 2008 to 2012 , and it can be linked with the situation in the Croatian economy and recession.

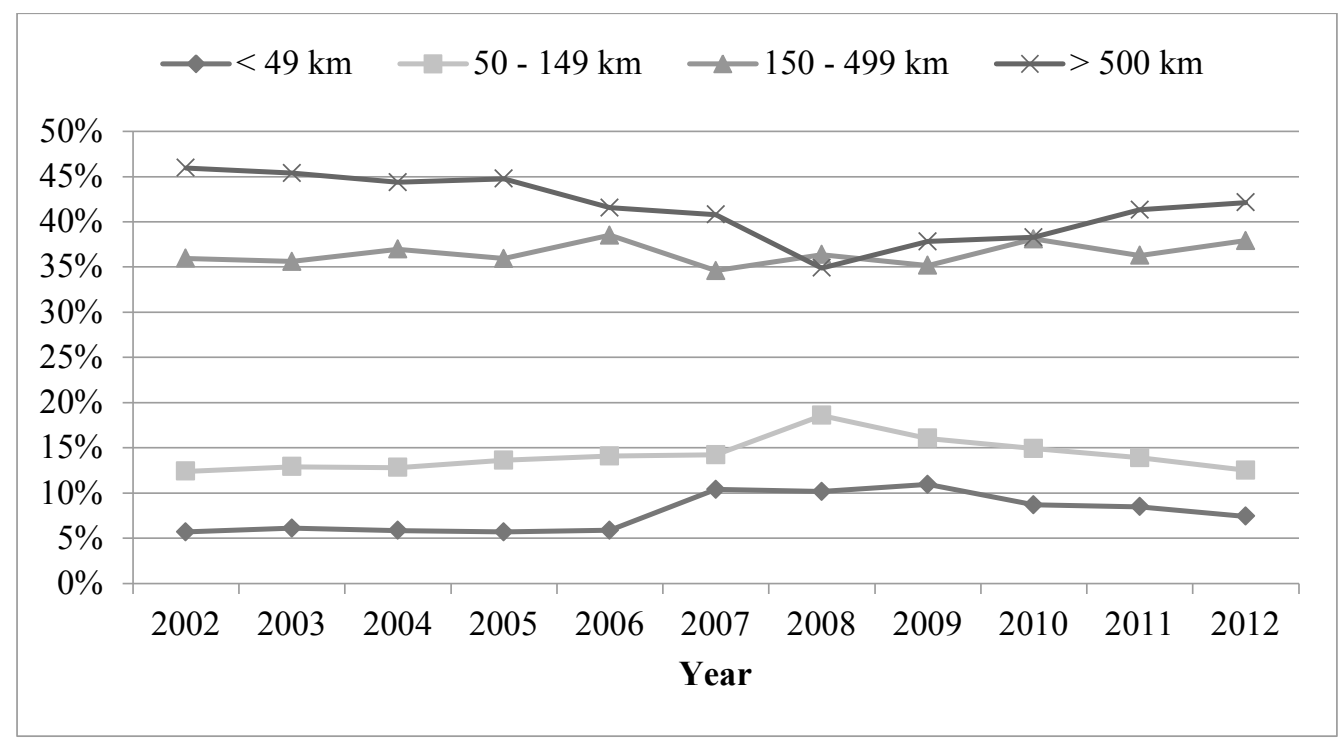

Figure 4 The relative structure of freight transport performance dynamics according to transport relations in the Croatian road transport system for the period from 2002 to 2012; Source: Tab. 4

Through additional studies of the dynamics and trends in absolute and relative structure of road freight transport substrate as well as the dynamics of absolute and relative structure of the realised freight transport performance according to certain categories of transport relations within the observed period, models are designed for those variables for which statistically significant mathematical prognostic trend models have been established (significance level $p<0,01$ ).

$$
\begin{aligned}
& Y=-7,905 x+81,163 \\
& R^{2}=0,95 \quad(p<0,01)
\end{aligned}
$$




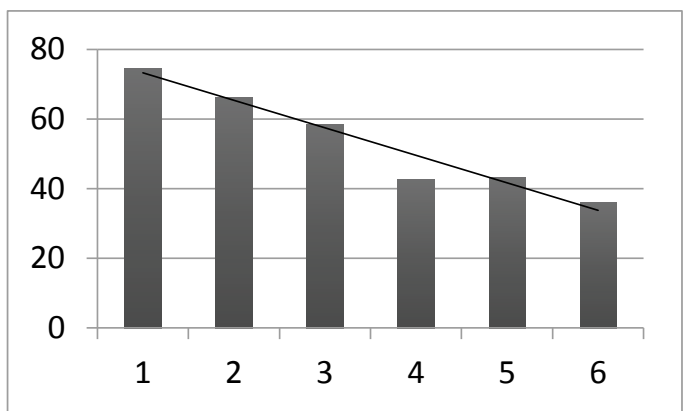

Figure 5 The amount of road freight substrate in the Croatian transport system at distances up to 49 kilometers in the period from 2007 to 2012 $(x=1$ for 2007); Source: Tab. 1

According to the mathematical prognostic trend model of road freight transport substrate in the Croatian transport system (Eq. (1)) and the associated value of the coefficient of determination $R^{2}$ (Eq. (2)), a statistically significant downward trend was achieved (significance level $p<0,01$ ) for this variable at distances up to 49 kilometres in the period from 2002 to 2007.

The share of road transport substrate at distances from 50 to 149 kilometres, has astatistically significant upward trend in the period from 2002 to 2008. (Fig. 6) After that, coupled with the impact of the economic crisis, there comes almost the same statistically significant downward trend in the value of the transport demand until the end of the period, ie. year 2012.

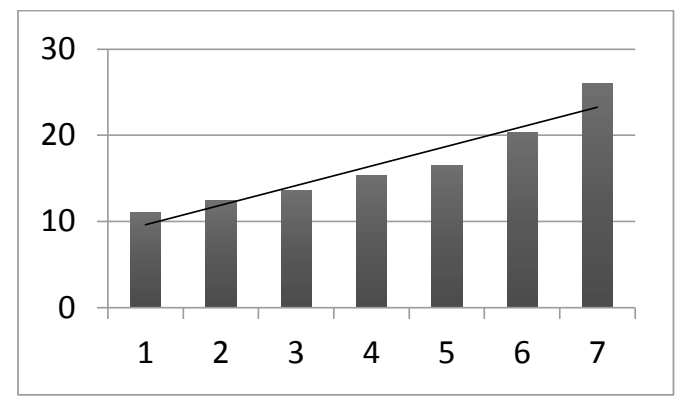

Figure 6 The amount of road freight substrate in the Croatian transport system at distances from 50 to 149 kilometres in the period from 2002 to 2008 ( $x=1$ for 2002); Source: Tab. 1

$Y=-2,2725 x+7,3719$

$R^{2}=0,90 \quad(p<0,01)$

According to the mathematical prognostic trend model of road freight transport substrate in the Croatian transport system (Eq. (3)) and the associated value of the coefficient of determination $R^{2}$ (Eq. (4)), a statistically significant upward trend was achieved (significance level $p<0,01)$ for this variable at distances from 50 to 149 kilometres in the period from 2002 to 2008 .

$Y=-2,8216 x+26,506$

$R^{2}=0,85 \quad(p<0,01)$

According to the mathematical prognostic trend model of road freight transport substrate in the Croatian transport system (Eq. (5)) and the associated value of the coefficient of determination $R^{2}$ (Eq. (6)), a statistically significant downward trend was achieved (significance level $p<0,01$ ) for this variable at distances from 50 to 149 kilometres in the period from 2008 to 2012.

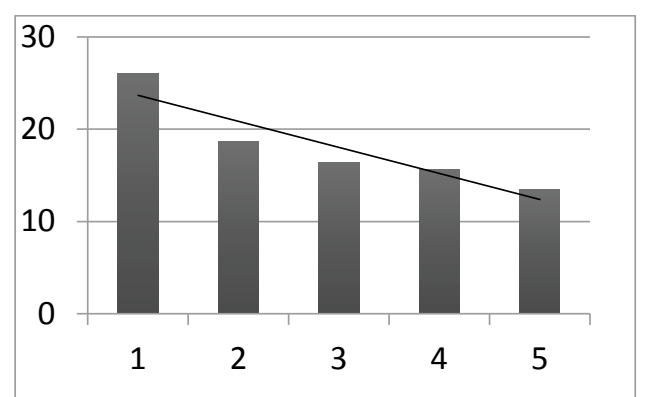

Figure 7 The amount of road freight substrate in the Croatian transport system at distances from 50 to 149 kilometres in the period from 2008 to 2012 ( $x=1$ for 2008); Source: Tab. 1

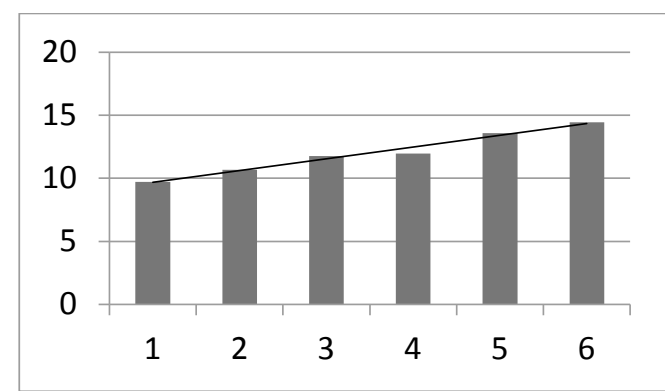

Figure 8 The amount of road freight substrate in the Croatian transport system at distances from 150 to 499 kilometres in the period from 2002 to 2007 ( $x=1$ for 2002); Source: Tab. 1

$Y=0,9295 x+8,7595$

$R^{2}=0,98 \quad(p<0,01)$

According to the mathematical prognostic trend model of road freight transport substrate in the Croatian transport system (Eq. (7)) and the associated value of the coefficient of determination $R^{2}$ (Eq. (8)), a statistically significant upward trend was achieved (significance level $p<0,01)$ for this variable at distances from 150 to 499 kilometres in the period from 2002 to 2007.

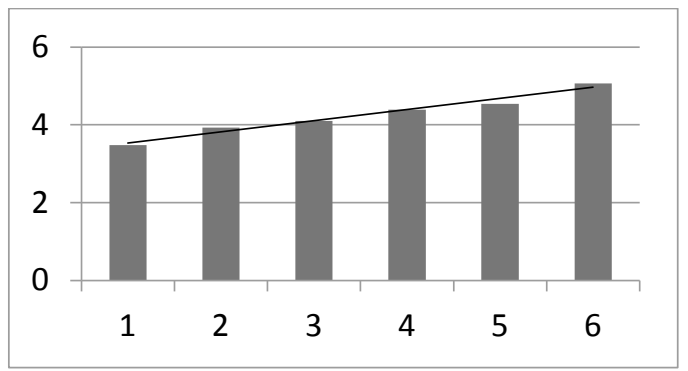

Figure 9 The amount of road freight substrate in the Croatian transport system at distances greater than 500 kilometres in the period from 2002 to 2007 ( $x=1$ for 2002); Source: Tab. 1

$Y=0,2863 x+3,246$

$R^{2}=0,97 \quad(p<0,01)$

According to the mathematical prognostic trend model of road freight transport substrate in the Croatian transport system (Eq. (9)) and the associated value of the coefficient of determination $R^{2}$ (Eq. (10)), a statistically significant upward trend was achieved (significance level 
$p<0,01)$ for this variable at distances greater than 500 kilometres in the period from 2002 to 2007

According to the realised freight transport performance, situation is completely different compared to the amount of road freight transport substrate, wherein the maximum value of realised transport performance is with the distances over $500 \mathrm{~km}$, then with relations from 150 to $499 \mathrm{~km}$, followed by relations from 50 to $149 \mathrm{~km}$, and the relations up to $49 \mathrm{~km}$. On all relations, a positive growth trend of the transport performance was being achieved until 2007. After 2007, at distances up to 49 kilometers and over $500 \mathrm{~km}$ a downward trend value was achieved, while at distances from 50 to $149 \mathrm{~km}$ and from 150 to $499 \mathrm{~km}$ an upward trend value was achieved all until 2008. After 2008, on all the transport relations a downward trend in transport performance was achieved until 2010, after which the transport relations over $500 \mathrm{~km}$ achieve an upward trend and they dominate with their relative share in the total realised transport performance. In contrast, transport performance in other categories of transport relations has a downward trend until 2012.

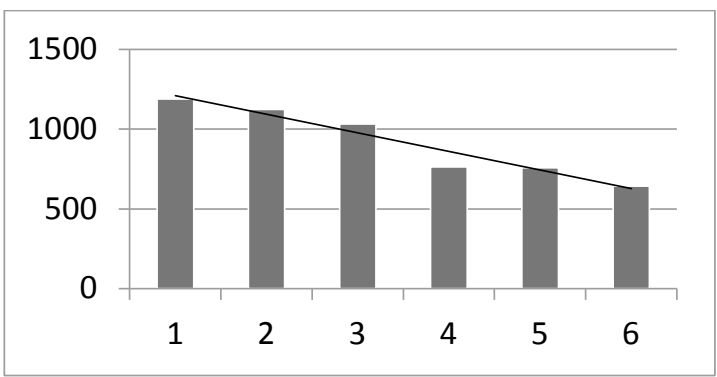

Figure 10 Freight transport performance at distances up to $49 \mathrm{~km}$ in the period from 2007 to 2012 ( $x=1$ for 2007); Source: Tab. 3

$\mathrm{Y}=-116,89 x+1326,9$

$R^{2}=0,94 \quad(p<0,01)$

According to the mathematical prognostic trend model of road freight transport performance on transport relations up to $49 \mathrm{~km}$ in the Croatian transport system (Eq. (11)) and the associated value of the coefficient of determination $R^{2}$ (Eq. (12)), a statistically significant downward trend was achieved (significance level $p<$ 0,01 ) for this variable in the period from 2007 to 2012 .

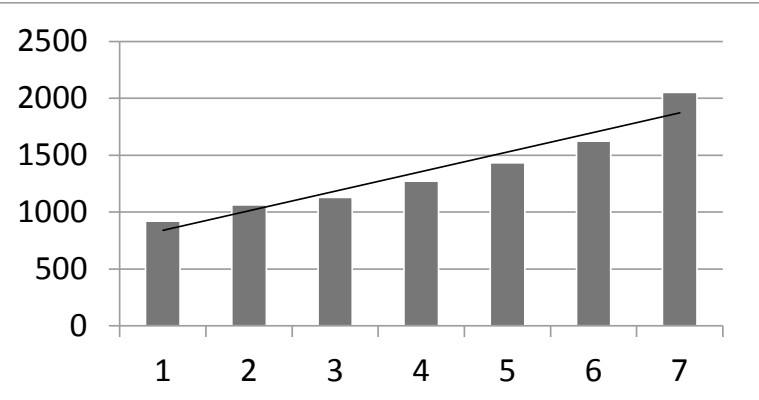

Figure 11 Freight transport performance at distances from 50 to $149 \mathrm{~km}$ in the period from 2002 to 2008; Source: Tab. 3

$Y=-172,14 x+667,43$

$R^{2}=0,93 \quad(p<0,01)$
According to the mathematical prognostic trend model of road freight transport performance on transport relations from 50 to $149 \mathrm{~km}$ in the Croatian transport system (Eq. (13)) and the associated value of the coefficient of determination $R^{2}$ (Eq. (14)), a statistically significant upward trend was achieved (significance level $p<0,01)$ for this variable in the period from 2008 to 2012.

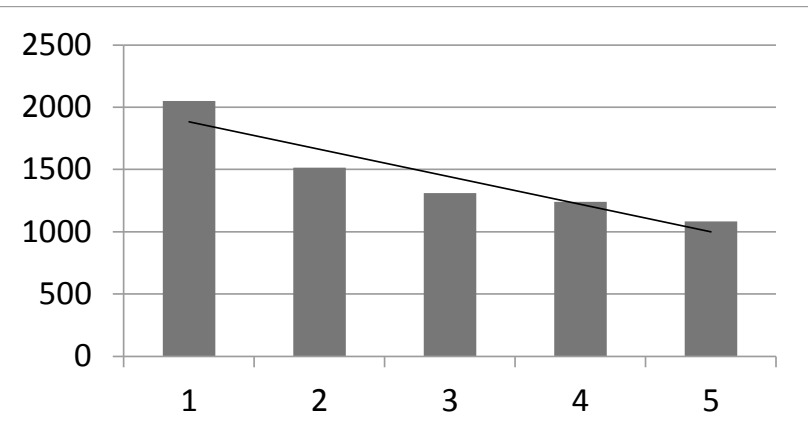

Figure 12 Freight transport performance at distances from 50 to $149 \mathrm{~km}$ in the period from 2008 to 2012; Source: Tab. 3

$Y=-220,8 x+2102$

$R^{2}=0,87 \quad(p<0,01)$

According to the mathematical prognostic trend model of road freight transport performance on transport relations from 50 to $149 \mathrm{~km}$ in the Croatian transport system (Eq. (15)) and the associated value of the coefficient of determination $\mathrm{R}^{2}$ (Eq. (16)), a statistically significant downward trend was achieved (significance level $p<0,01$ ) for this variable in the period from 2008 to 2012.

\section{Conclusion}

According to research conducted in the Croatian road transport, short distances up to $49 \mathrm{~km}$ have the biggest share in meeting freight transport demand. On these transport relations there is more than $50 \%$ of total road transport substrate. On the other transport relations during the observed period, transport demand decreases due to the increase in distance. Relations that dominate with regard to freight transport performance are the relations over $500 \mathrm{~km}$, followed by relations from 150 to $499 \mathrm{~km}$. After analyzing the absolute structure of road freight transport substrate, it can be concluded that in the Croatian road transport system in the period from 2002 to 2012: a) the average amount of total road freight transport substrate is 73562 million tons, with an average annual growth rate of road freight transport substrate at 3,6 \%, b) at distances up to $49 \mathrm{~km}$ an average of 40920 million tons of road freight substrate was transported, with an average annual growth rate of $5,2 \%, \mathrm{c}$ ) at distances from 50 to $149 \mathrm{~km}$ an average of 16311 million tons of cargo was transported, with an average annual growth rate of $2 \%, d$ ) at distances from 150 to $499 \mathrm{~km}$ an average of 12218 million tons of freight substrate was transported, with an average annual growth rate of $2,2 \%$, e) at distances over $500 \mathrm{~km}$ an average of 4112 million tons was transported, with an average annual growth rate of $1 \%$. By analyzing 
the absolute structure of freight transport performance according to established categories of transport relations in the Croatian road freight transport in the period from 2002 to 2012, it can be concluded that: a) realised freight transport performance at distances up to $49 \mathrm{~km}$ amounts on average to 734 million tonne-kilometers (hereinafter tonne kilometers $=\mathrm{tkm}$ ), with an average annual growth rate of $4,3 \%$, b) realised freight transport performance at distances from 50 to $149 \mathrm{~km}$ amounts on average to 1331 million tkm, with an average annual growth rate of $1,7 \%$, c) at distances from 150 to $499 \mathrm{~km}$, the average value of transport performance is 3389 million tkm, with an average annual growth rate of $21 \%$, d) relations which showed the most significant value of the resulting transport effect are relations over $500 \mathrm{~km}$, with an average value of 3840 million tkm, and the average annual growth rate of $0,7 \%$, e) the average value of the total transport performance was 9294 million tkm, while the average annual growth rate was $1,5 \%$. By analyzing the relative structure of the realised freight transport performance according to transport relations in the Croatian road freight transport in the period from 2002 to 2012, it is possible to state the following: a) at distances up to 49 $\mathrm{km}, 7,8 \%$ of the total transport work was realised, with an average annual growth rate in the relative share of 2,7 $\%$, b) at distances from 50 to $149 \mathrm{~km}, 14,2 \%$ of the total transport performance was realised, with an average annual growth rate in the relative share of $0,1 \%, c)$ at distances from 150 to $499 \mathrm{~km}, 39,5 \%$ of the total transport performance was realised, with an average annual growth rate in the relative share of $0,5 \%$, d) at distances over $500 \mathrm{~km}$ an average of $41,6 \%$ of the total transport performance was realised, with an average annual rate of decline in the relative share of $-0,9 \%$. Through additional studies of the dynamics and trends in absolute and relative structure of road freight transport substrate as well as the dynamics of absolute and relative structure of the realised freight transport performance according to certain categories of transport relations within the observed period, models are designed for those variables for which statistically significant mathematical prognostic trend models have been established (significance level $p<0,01$ ).

\section{References}

[1] Hensher, D. A.; Button, K. Handbook of Transport Modelling, University of Sydney, George Mason University, Elsevier Science Ltd., Oxford, 2000, pp. 1-10.

[2] Rajsman, M. Traffic System Development Model of Middle Croatia, Doctoral thesis, Faculty of Transport and Traffic Sciences, University of Zagreb, 2005

[3] Hensher, D. A.; Button, K. Handbook of transport systems and traffic control, University of Sydney, George Mason University, Elsevier Science Ltd., Oxford, 2001, pp, 9-19, 47-107.

[4] Banister, D. Transport planning, according to Hensher D. A.; Button K. Handbook of transport systems and traffic control, University of Sydney, George Mason University, Elsevier Science Ltd., Oxford, 2001, pp. 9-19. DOl: 10.1108/9781615832460-002

[5] Dunn J. A. Driving forces - the automobile, its enemies and politics of mobility, Washington, Brooking Institution, 1998, according to Hensher, D. A.; Button, K. Handbook of transport systems and traffic control, University of Sydney,
George Mason University, Elsevier Science Ltd., Oxford, 2001, pp. 10.

[6] http://www.dzs.hr/Hrv_Eng/publication/2013/SI-1493.pdf, p. $40,13 / 07 / 2014$

[7] Vickerman, R. The concept of Optimal Transport Systems, according to Hensher D. A.; Button K. Handbook of transport systems and traffic control, University of Sydney, George Mason University, Elsevier Science Ltd., Oxford, 2001, pp. 47-58. DOI: 10.1108/9781615832460-005

[8] Padjen, J. Prijevozna potražnja i oblik hrvatskoga državnog prostora - važne determinante prometne politike Hrvatske. // Ceste i mostovi. 3-4(2002), pp. 71-80.

[9] Statistical Reports 1327/2007: Transport and Communications in 2006, Central Bureau of Statistics, Zagreb.

[10] Statistical Reports 1465/2012: Transport and Communications in 2012, Central Bureau of Statistics, Zagreb.

[11] Statistical Reports 1493/2013: Transport and Communications in 2012, Central Bureau of Statistics, Zagreb.

\section{Authors' addresses}

Marijan Rajsman, Ph.D. Assoc. Prof.

Faculty of Transport and Traffic Sciences, University of Zagreb,

Vukelićeva ul. 4, 10000, Zagreb, Croatia

E-mail: mrajsman@fpz.hr

Grgo Luburić, Ph.D. Assoc. Prof.

Faculty of Transport and Traffic Sciences, University of Zagreb,

Vukelićeva ul. 4, 10000, Zagreb, Croatia

E-mail: gluburic@fpz.hr

Matija Muhin, Bacc. ing. traffic

E-mail:matmuhin@gmail.com 